ISSN 2078-6441. Вісник Львівського університету. Серія географічна. 2018. Випуск 52. С. 170-182.

Visnyk of the Lviv University. Series Geography. 2018. Issue 52. P. 170-182.

http:/ / dx.doi.org/10.30970/vgg.2018.52.10183

379.85

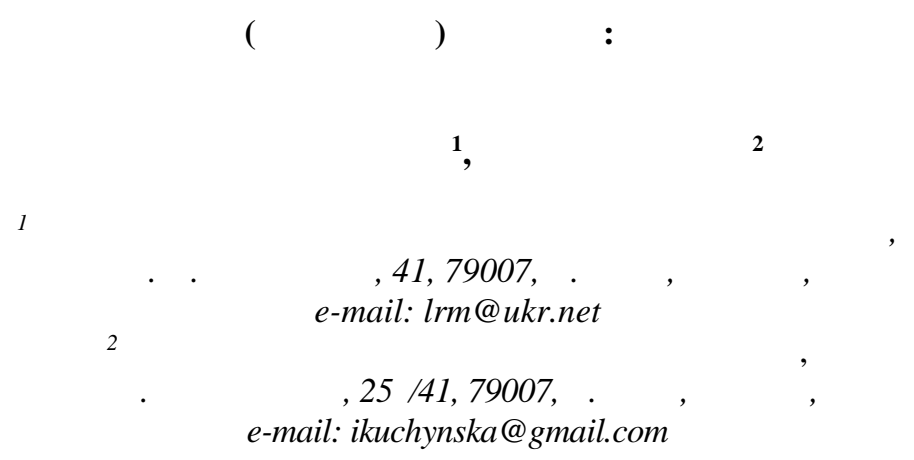

ост нні десятиріччя в кр їні в н уковій т н вч льній літер турі широко використовують термін "спеці лізов ний туризм". н ліз публік цій з свідчує, що він позн ч є сукупність видів туризму, які в іноземній літер турі н йч стіше об'єдн ні поняттям “нішевий туризм”. е один нгломовний термін - “туризм спеці льного інтересу” - хоч і близький з звуч нням до укр їнського “спеці лізов ний туризм", н спр вді позн ч $€$ інший з змістом т обсягом виду туризму.

икорист ння різних термінів зумовлене відмінностями економік, які функціонув ли в минулому у т. зв. “К піт лістичних" й “соці лістичних" кр їн х. умов х ринкової економіки в 3 хідній н уковій літер турі виник м ркетинговий термін “ринков ніш ", який і використ но для створення поняття "нішевий туризм". томість у колишньому 3 умов дміністр тивнорегульов ної економіки х р ктернішим було вжив ння понять “спеці ліз ція", “г лузь спеці ліз ції”, тому з'явився термін “спеці лізов ний туризм”.

н ліз розвитку концепції спеці лізов ного (нішевого) туризму в укр їнській і з рубіжній н уковій літер турі д в можливість уточнити його суч сний зміст. пеці лізов ний (нішевий) туризм - це сукупність видів туризму, орієнтов них н чітко окреслені й відносно ст лі групи туристів (об'єдн ні з мотив ми подорожі, спеці льними потреб ми туристів чи особливостями туристичної дестин ції), що формують певний вузький цільовий сегмент ринку (мікронішу), дост тній з величиною для створення окремих туристичних продуктів.

йв жливіші озн ки, які д ють змогу віднести певний вид туризму до спеці лізов ного, т кі: н явність чітко окресленої і відносно ст лої цільової групи туристів; виділення ринкової ніші н основі сегмент ції ринку спожив чів; орієнт ція н вузький цільовий сегмент бо н мікроринок; дост тність ніші для створення окремих туристичних продуктів; дресний, чітко визн чений туристичний продукт, тісно підігн ний під специфічні вимоги спожив чів.

лючові слов : туризм, види туризму, спеці лізов ний туризм, нішевий туризм, туризм спеці льного інтересу.

уч сні тенденції розвитку туризму, його постійне ускл днення т диверсифік ція, ведуть до появи великої кількості нових оригін льних туристичних продуктів щороку. рост є популярність нових видів туризму, орієнтов них н доволі вузькі сегменти туристів. ля їхнього позн чення в кр їні в н уковій т н вч льній туризмозн вчій літер турі впродовж ост ннього десятиріччя використовують термін “спеці лізов ний туризм”. н вч льні пл ни низки вищих н вч льних $з$ кл дів, що готують студентів 3

(c) озинський ., учинськ ., 2018 
спеці льністю “ уризм” включено н вч льну дисципліну “ пеці лізов ний туризм”, з'явилися перші посібники. одноч с єдиного розуміння цього поняття в середовищі туризмозн вців н сьогодні нем є, воно потребує уточнення.

$m$ мет - вст новлення сутності поняття “спеці лізов ний туризм” т його місця в $з$ г льній системі туризмологічних зн нь н основі н лізу вітчизняних т іноземних літер турних джерел.

онцепція спеці лізов ного туризму в кр їні розвив ється впродовж трив лого періоду, тому кількість теоретичних публік цій, які т к чи ін кше стосуються цієї проблем тики, є доволі зн чною. окрем, в укр їнській н уковій літер турі визн чення спеці лізов ного туризму зн ходимо в пр цях . р чил , . б рицької т . линовської, . іптенк, . молія, . едорченк т . ибух . либший н ліз змісту поняття т його структури здійснили у своїх публік ціях . у утч кі утч к, . стименко, - ндрєєв i . ов ль. еред вторів інших кр їн постр дянського простору в рто зг д ти . бкін, . іржков , . оголюбов, . рядову і . він . он йв жливіших іноземних джерел, в яких досліджено теоретичні з с ди розвитку "нішевого туризму” т “туризму спеці льного інтересу” відносимо пр ці т ких вторів: . овеллі (M. Novelli), ж. іч т . едвік (J. Beech i S. Chadwick), . ерретт (R. Derrett), міт, . кл уд т . . обертсон (N. Smith, N. Macleod, M. H. Robertson), . олл i . йлер (M. Hall, B. Weiler), ж. ворбрук і . орнер (J. Swarbrook, S. Horner) т iн. ольщі тем тикою близького з змістом кв ліфіков ного туризму з йм лися . обожевич (Т. Łobo ewicz), . урек, . ік т . ітрус (W. Kurek, M. Mika, E. Pitrus), уридівк (M. Durydiwka), . оньч к (B. Bończak), . окр с- р бовськ (J. Mokras-Grabowska) т ін.

оняття “спеці лізов ний туризм" в н уковій літер турі в кр їні використовують уже щон йменше три десятиліття. Г льн кількість ст тей і моногр фій, у яких його н лізують, т кож н водять визн чення, є доволі зн чною. ому виділимо лише н йв жливіші публік цій, які, н н шу думку, відобр ж ють еволюцію поглядів н це поняття (див. т бл. 1).

е у 1987 p. р чило у підручнику “ еогр фія туризму” виділив “пізн в льноділовий, бо спеці лізов ний, туризм”, який “охоплює групи людей, об'єдн них єдиною метою бо професійними інтерес ми”. його погляд, “ е можуть бути інженери, лік рi, пед гоги, ф хівці сільського господ рств $m$ інші, які вчиняють туристські подорожі з спеці льними прогр м ми ім ршрут ми. о нихможн віднести туристів, якін л годжують ділові конт кти, вчених $і$ ф хівців, які беруть уч сть в роботі конферениій, конгресів, з'їзів, с мблей, симпозіумів, семін рів, і осіб, які приїх ли до рідних, близьких, зн йомихн відпочинок" [9].

ке тр ктув ння спеці лізов ного туризму пов'язує його з поняттям “професії” (“спеці льності”). погляду суч сності це визн чення вид ється доволі суперечливим, ле потрібно вр хув ти, що воно з'явилося 30 років тому, в колишньому, , де розвиток туризму м в суттєву специфіку, зумовлену неринковим х р ктером економіки.

1999 p. . утч к $\mathrm{i}$. утч к у ст тті [6] з пропонув ли т ке визн чення спеці лізов ного туризму: “систем окремих сегментів туризму, в основу виділення яких пост влен мет подорожі" [6]. они поділили спеці лізов ний туризм н сім великих сегментів (курортно-лікув льний, комерційно-діловий, релігійний, пізн в льно-культурнорозв ж льний, екологічний, спортивно-оздоровчий, екзотичний туризм), сегменти, в 
свою чергу, н підвиди н основі семи критеріїв. ктично втори ототожнили види спеці лізов ного туризм з його кл сифік цією $з$ метою подорожі, підвиди - 3 кл сифік цією н основі інших критеріїв. н ш погляд, в основі т кого тр ктув ння є 3 г льновідомі в економічній літер турі поняття “спеці ліз ція”, “г лузь спеці ліз ції, які виникли у процесі суспільного розподілу пр ці. ке тр ктув ння спеці лізов ного туризму є дуже широким. дн к потрібно вр хув ти, що цю ст ттю н пис но у період, коли туристичн г лузь в кр їні (як з г лом економік держ ви) лише виходил із 3 тяжної кризи, зумовленою розп дом т переходом до ринкової економіки. системі вищої освіти кр їни н той ч с ще н віть не існув ло окремої спеці льності “ уризм”. цей період с м ф кт появи ст тті про “спеці лізов ні види туризму” уже м в велике позитивне зн чення.

блиия 1

оняття “спеці лізов ний туризм” у пр цях укр їнських дослідників

т н уковців постр дянського простору

\begin{tabular}{|c|c|}
\hline в тор, рік & изн чення \\
\hline р чило ., 1987 & $\begin{array}{l}\text { ізн в льно-діловий бо спеці лізов ний туризм охоплює групи } \\
\text { людей, об'єдн них єдиною метою бо професійними інтерес ми. } \\
\end{array}$ \\
\hline $\begin{array}{lll}\text { УтЧ к } & ., \\
\text { утч к } & ., 1999 \\
\end{array}$ & $\begin{array}{l}\text { пеці лізов ний туризм - це систем окремих сегментів туризму, в } \\
\text { основу виділення яких пост влен мет подорожі. }\end{array}$ \\
\hline $\begin{array}{l}\text { б рицьк ., } \\
\text { линовськ ., } 2004 \\
\text { іптенко ., } 2010\end{array}$ & $\begin{array}{l}\text { пеці лізов ний туризм - термін, що використовують для позн - } \\
\text { чення туристів, які купують спеці лізов ний тур і виїждж ють з ме- } \\
\text { тою вивчення специфічних особливостей тієї чи іншої місцевості, для } \\
\text { отрим ння особистого досвіду, викон ння спортивних норм тивів, } \\
\text { ктивного відпочинку тощо. }\end{array}$ \\
\hline $\begin{array}{l}\text { молій ., } \\
\text { едорченко ., } \\
\text { ибух ., } 2006\end{array}$ & $\begin{array}{l}\text { пеці лізов ний туризм - вид туристської діяльності, мет якого - } \\
\text { ре лізув ти специфічні з пити людей під ч с поїздки, відвідув ння } \\
\text { об'єкту. меж х спеці лізов ного туризму особливу ув гу можуть } \\
\text { приділяти широкому ді п зону пит нь, пов'яз них з вивченням куль- } \\
\text { тури, природи, т кож з професійними і різного виду спортивно- } \\
\text { туристськими потреб ми туристів. }\end{array}$ \\
\hline стименко ., 2013 & $\begin{array}{l}\text { пеці лізов ний туризм - це систем видів туризму, які визн чені } \\
\text { окремими сегмент ми, в основу виділення яких пост влен певн } \\
\text { мет подорожі, с м м ндрівк вим г є спеці льної орг ніз ції т } \\
\text { відповідних туристичних ресурсів. }\end{array}$ \\
\hline $\begin{array}{l}\text { ндрєєв } \\
\text { ов ль ., } 2015\end{array}$ & $\begin{array}{l}\text { пеці лізов ний туризм - це тимч совий виїзд особи з місця прожи- } \\
\text { в ння з метою подорожі, що є спеці лізов ною щодо з г льноприй- } \\
\text { нятих (оздоровчих, пізн в льних, професійно-ділових), без здійс- } \\
\text { нення опл чув ної діяльності в місці, куди особ від'їждж є. }\end{array}$ \\
\hline бкін ., 2008 & $\begin{array}{l}\text { о спеці льних видів туризму можн віднести тури, які повністю бо } \\
\text { ч стково сх р ктеризов ні т кими озн к ми: 1) нем сові, дост тньо } \\
\text { рідкісні види туризму; 2) трудомісткі } 3 \text { створенням кінцевого } \\
\text { турпродукту; 3) к піт ломісткі види туризму; 4) тури, що поєднують } \\
\text { озн ки різних видів туризму; 5) нові види туризму, зумовлені вторин- } \\
\text { ними потреб ми людини; 6) види туризму з використ нням нетр ди- } \\
\text { ційних джерел фін нсув ння. }\end{array}$ \\
\hline
\end{tabular}

жерело [1-3, 6-9, 11]. 
н ступні роки з'явилося ще декільк доволі широких тр ктув нь поняття “спеці лізов ний туризм” ( . б рицьк , i . линовськ ; . молій, . едорченко і . ибух), які зосереджув ли ув гу н специфічних особливостях тієї чи іншої місцевості, отрим нні турист ми особистого досвіду, специфічних з пит х людей під ч с поїздки тощо [2, 7].

н чний вплив н поширення терміну спеці лізов ний туризм у кр їн х, що виникли після розп ду , в тому числі в кр їні, м л книг російського втор . бкін “ пеці льні види туризму”, що вийшл у 2008 р. в остові-н - ону. осил ння н його визн чення спеці лізов ного туризму доволі ч сто можн зустріти у пр цях зі спеці лізов ного туризму н усьому постр дянському просторі. основі цієї книги скл дено н вч льні прогр ми із предмету “ пеці лізов ний туризм” у деяких вищих н вч льних 3 кл д х кр їни.

ля обгрунтув ння виділення спеці льних видів туризму . бкін використ в поняття “м совий конвеєрний туризм” і “м совий диференційов ний туризм”. ерший передб ч є відносний примітивізм і однорідність потреб т мотив ції туристів, невиp зно-конвеєрний х р ктер н д них послуг. кий туризм перев ж в до ругої світовій війни. иференційов ний туризм відрізняє різном нітн п р дигм потреб і мотив цій туристів, множинність вузькоспеці лізов них сегментів у туристському попиті, різном нітність пропонов них послуг і яскр во вир жен спеці ліз ція туристського пропозиції. ідповідно, перехід до м сового диференційов ного туризму супроводжув вся поширенням спеці льних видів туризму [3, с. 19].

о спеці льних видів туризму втор відніс тури, які повністю бо ч стково м ли т кі озн ки: 1) нем сові, доволі рідкісні види туризму; 2) трудомісткі зі створення кінцевого турпродукту; 3 ) к піт ломісткі види туризму; 4) тури, що поєднують озн ки різних видів туризму; 5) нові види туризму, обумовлені вторинними потреб ми людини; 6) види туризму з використ нням нетр диційних джерел фін нсув ння. н ш погляд, цей перелік озн к є дуже широким, деякі озн ки - неконкретними, які передб ч ють різне тр ктув ння. икористовуючи їх, до спеці льних можн віднести більшість видів туризму. перелік н йпоширеніших спеці льних видів туризму . бкін включив: релігійний, діловий (передусім конгресно-вист вковий і інсентив-туризм), лікув льно-оздоровчий, екологічний, подієвий, гірськолижний, екстрем льний, круїзний [3, с. 19].

отрібно з зн чити, що з г лом н поч тку ст., вплив російської н вч льної літер тури н процес підготовки ф хівців з туризму в кр їні був дуже зн чним. відсутності якісних укр їнських підручників з туризму, книги російських вторів м сово використовув ли у н вч льному процесі, н їхній основі розроблялися н вч льні прогр ми з різних предметів, вид в ли перші, ч сто компілятивні, укр їнські підручники й посібники. окрем, у процесі вивчення спеці лізов них видів туризму в кр їні, крім н зв ного вище вид ння - бкін, використовують т кож н вч льні посібники російських вторів . ірж ков [4], . оголюбов [5], . рядової і . він [10].

оволі широке і неконкретизов не розуміння поняття “спеці лізов ний туризм” збереглося в укр їнській н вч льній літер турі до сьогодні. прикл д, . іптенко у підручнику “ енеджмент туризму” (2010) з зн ч в, що спеці лізов ний туризм - це туризм, який здійснюють з метою вивчення специфічних особливостей того чи іншого місця, н дб ння індивіду льного досвіду, викон ння спортивних норм тивів, ктивного відпочинку т ін. вітчизняній пр ктиці це здебільшого с модіяльний і спортивний туризм; у міжн родній розрізняють т кі його види: пригодницький, екотуризм, етнічний (ност льгічний), сільський (зелений), фермерський туризм т ін. [8]. е визн чення, н 
н ш погляд, $є$ ще менш конкретним, ніж попередні, дже можн стверджув ти, що будьяке місце м є певні специфічні особливості, будь-як туристичн подорож сприяє н д нню певного індивіду льного досвіду. ідповідно, усі туристичні поїздки можн віднести до спеці лізов ного туризму. рім цього, н вряд чи доцільним є віднесення с модіяльного туризму до спеці лізов них видів. дже його виділяють 3 критерієм орг ніз ції подорожі, у більшості видів туризму можуть бути як с модіяльні, т к і орг нізов ні тури.

. ндрєєв і . ов ль у ст тті “ еоретичні з с ди спеці лізов ного туризму” (2015), н н шу думку, н йближче підійшли до розуміння змісту досліджув ного поняття. изн ч ючи цей термін, вони відштовхув лися від теорії конкурентних перев г

. ортер, у якій виділяють конкурентну стр тегію спеці ліз ції (фокусув ння), що м $\in$ н меті вибір вузької сфери конкуренції у меж х певної г лузі, ін кше к жучи, вибір сегмент бо декількох сегментів ринку і обслуговув ння лише їх. ідповідно, “спеці лізов ний” - це т кий, що призн чений для окремого сегменту ринку. втори дійшли висновку, що “спеці лізов ний туризм - це тимч совий виїзд особи з місия прожив ння з метою подорожі, що $е$ спещі лізов ною щодо $з$ г льноприйнятих (оздоровчих, пізн в льних, професійно-ділових), без здійснення опл чув ної діяльності в місці, куди особ від’їждж $е$ " [1]. ля кл сифік ції видів спеці лізов ного туризму . ндрєєв i . ов ль 3 пропонув ли озн ку мети подорожі. они виділили шість “основних" сегментів спеці лізов ного туризму: пізн в льний, рекре ційний, діловий, розв ж льний, пригодницький, природний, у меж х кожного сегменту - до 15 спеці лізов них видів туризму [1]. н ш погляд, 3 сутністю т ке тр ктув ння близьке до визн чення, з пропонов ного 1999 р. . утч к i . утч к, дже в його основі т кож є мет подорожі. . ндрєєвої i . ов ля лише дещо скл дніше теоретичне обгрунтув ння. одноч с вислів “мет подорожі, що є спеці лізов ною щодо $з$ г льноприйнятих”, н н ш погляд, є не зовсім вд лим. дже з лиш ється незрозумілим, що т ке “з г льноприйнят ” мет подорожі, і чому, н прикл д, втори віднесли до з г льноприйнятих професійно-ділові подорожі, які т кож ч сто м ють вузькоспеці лізов ну мету.

нгломовній з рубіжній літер турі впродовж ост нніх десятиріч ктивно використовують термін “special interest tourism” (SIT), який н укр їнську мову перекл д ється як “туризм спеці льних інтересів” ( бо “туризм спеці льного інтересу”), хоч можливим є перекл д як “туризм особливих інтересів" чи “туризм індивіду льних інтересів”. о p нніх вип дків концепту льного виділення спеці лізов ного туризму відносимо ст ттю S. Read ( . ід ) “ ровідн сил у зрост нні туризму в н ступному десятилітті: подорож спеці льних інтересів”, що з'явил ся 1980 р. втор виділив окремий різновид турів “подорож спеці льних інтересів" (special interest travel), яку він визн чив як подорож людей з метою з доволення певного спеці льного (особливого) інтересу, який може бути ре лізов ний в певному (особливому) регіоні чи дестин ції [23] (див. т бл. 2).

1980-1990-х рок х SIT ст в своєрідним феноменом у розвитку світової туристичної г лузі. ількість спеці лізов них туристичних подорожей різко зросл , в зв'язку з чим збільшил ся кількість н укових публік цій, поклик них д ти визн чення цього явищ т розкрити його зміст.

окрем , M. Hall i B. Weiler ( . олл т . йлер) у книзі “ уризм спеці льного інтересу” (1992), стверджув ли, що до SIT відносять подорожі, у яких “мотив ція подо- 
рожснього $m$ ухв лення рішення передусім визн ч ється конкретним особливим інтересом 3 кцентом н певній діяльності бо дестин иії” [16, p. 5]. 1999 p. J. Swarbrook i S. Horner ( ж. ворбрук i . орнер) розширили це визн чення, вк 3 вши н нові спекти SIT. они, зокрем , з зн чили, що туризм спеці льного інтересу не лише сприяє розвитку уже сформов них інтересів спожив чів, ле й може розвинути новий інтерес до нового бо зн йомого місця [25, p. 5]. 2001 p. R. Derrett ( . ерет) визн чив SIT як "н д ння орієнтов них н спожив ч дозвілля $m$ розв г, обумовлених спеці льним вир жееним інтересом окремих осіб $m$ груn" [13, p. XVII].

блиия 2

оняття “нішевий туризм”, “туризм спеці льних інтересів”,

“Кв ліфіков ний туризм” в іноземній літер турі

\begin{tabular}{|c|c|c|}
\hline ермін & в тор, piк & изн чення \\
\hline \multirow[t]{4}{*}{$\begin{array}{l}\text { Niche tourism } \\
\text { (нішевий } \\
\text { туризм) }\end{array}$} & M. Novelli, 2005 & $\begin{array}{l}\text { пецифічні туристичні продукти, орієнтов ні н } 3 \text { до- } \\
\text { волення потреб конкретних сегментів ринку бо ніш. } \\
\text { льтерн тив м совому туризму в умов х зрост ючої } \\
\text { глоб ліз ції. } \quad \text { позичений } 3 \text { концепції нішевого } \\
\text { м ркетингу. }\end{array}$ \\
\hline & $\begin{array}{l}\text { J. Beech, } \\
\text { S. Chadwick, } 2006\end{array}$ & $\begin{array}{l}\text { евеликий, спеці лізов ний сектор туризму, що розр - } \\
\text { хов ний н дресний, чітко визн чений сегмент ринку. }\end{array}$ \\
\hline & $\begin{array}{l}\text { Developing a Niche } \\
\text { Tourism Market } \\
\text { Database for the } \\
\text { Caribbean, } 2008\end{array}$ & $\begin{array}{l}\text { ішевий туризм н цілений н специфічний ринковий } \\
\text { сегмент, з звич й з чітко визн ченим продуктом, який } \\
\text { може бути д птов ний до інтересів туристів. }\end{array}$ \\
\hline & $\begin{array}{l}\text { V. Zotic, } \\
\text { D. Alexandru, } \\
\text { S. Dezsi }\end{array}$ & $\begin{array}{l}\text { рієнтов ний н невелику, ле відносно ст луч стку } \\
\text { туристичного ринку. р ктеризується унік льністю, } \\
\text { дин мічністю, високою д птов ністю до потреб ту- } \\
\text { ристів, тісним вз ємозв’язком між туристичною пропо- } \\
\text { зицією і попитом н мікрорівні. }\end{array}$ \\
\hline \multirow{3}{*}{$\begin{array}{l}\text { Special interest } \\
\text { tourism (туризм } \\
\text { спеці льного } \\
\text { інтересу }\end{array}$} & $\begin{array}{l}\text { M. Hall, } \\
\text { B. Weiler, } 1992\end{array}$ & $\begin{array}{l}\text { отив ція подорожнього т ухв лення рішення визн - } \\
\text { ч ється передусім конкретним спеці льним інтересом } 3 \\
\text { кцентом н певній діяльності } \text { бо дестин ції. }\end{array}$ \\
\hline & R. Derrett, 2001 & $\begin{array}{l}\text { д ння орієнтов них н спожив ч дозвілля т розв г, } \\
\text { обумовлених спеці льним вир женим інтересом окре- } \\
\text { мих осіб т груп. }\end{array}$ \\
\hline & $\begin{array}{l}\text { M. Smith, } \\
\text { N. Macleod, M. Hart } \\
\text { Robertson, } 2010\end{array}$ & $\begin{array}{l}\text { оловн мет подорожі-з доволення певних спеці ль- } \\
\text { них інтересів туристів. ключ є форми туризму, сфо- } \\
\text { кусов ні т тих вид х діяльності, які прив блюють не- } \\
\text { велику кількість високо вмотивов них туристів. }\end{array}$ \\
\hline $\begin{array}{l}\text { Turystyka } \\
\text { kwalifikowana } \\
\text { (specjalistyczn ) } \\
\text { (кв ліфіков ний } \\
\text { туризм) }\end{array}$ & $\begin{array}{l}\text { T. Łobo ewicz, } \\
1983, \\
\text { W. Kurek, M. Mika, } \\
\text { E. Pitrus, 2007, } \\
\text { M. Durydiwka, 2010, } \\
\text { B. Bończak, 2013, } \\
\text { J. Mokras- } \\
\text { Grabowska, 2015 } \\
\end{array}$ & $\begin{array}{l}\text { йбільш спеці лізов н форм ктивного туризму. } \\
\text { р ктерними рис ми є: обов'язкові фізичні н в нт - } \\
\text { ження, необхідність особистої кв ліфік ції турист , } \\
\text { спеці льної психофізичної т інтелекту льної підго- } \\
\text { товки, в окремих вип дк х - користув ння спеці льним } \\
\text { спорядженням, т кож кв ліфік ція досягнень турист } \\
\text { у вигляді певних рівнів чи відзн к. }\end{array}$ \\
\hline
\end{tabular}

жерело [12-21, 21, 24, 26]. 
е одним поняттям, близьким з сутністю до спеці лізов ного туризму, у з рубіжній н уковій літер турі є “нішевий туризм" (niche tourism). онцепція "нішевого туризму” виникл в туризмі в ост нні десятиріччя н против гу тому, що з звич й н зив ють “м совим туризмом”. совий туризм є трибутом кл сичної індустрі льної (“фордистської”) економіки. ін пов'яз ний з кл сичними п кетними тур ми (package tour), які пропонує невелик кількість вертик льно т горизонт льно інтегров них опер торів, що домінують н ринку, і передб ч $є$ екстенсивне зрост ння кількості туристичних курортів, готелів і т. п. ішевий туризм пов'язують з переходом до постіндустрі льної (“пост-фордистської” бо “неофордистської”) економіки, у якій спожив чі визн ч ють виробничі процеси, п нує гнучк спеці ліз ція.

ермін “нішевий туризм” виводять з терміну “ринков (м ркетингов ) ніш ”, який, у свою чергу, створено 3 н логією з “екологічною нішею”. икорист ння терміну "ринков ніш ” передб ч є дв спекти, с ме н явність н ринку місця для певного продукту т спожив чів цього продукту. уристичний ринок нішевих спожив чів пост є як поєдн ння людей зі спеці лізов ними потреб ми чи інтерес ми, для яких потрібно створюв ти нішеві туристичні продукти.

озвиток нішевих видів туризму д є чим ло перев г для туризму менеджменту туристичних дестин цій. $\mathrm{x}$ x р ктеризують стійкішим попитом, вони є сприятливішими для місцевих спільнот і, що в жливо, дозволяють з лучити з можніших туристів. ля туристів нішевий туризм н д є новий цік вий досвід. ому сесвітня орг ніз ція туризму $(U N W T O)$ i сесвітня р д 3 пит нь подорожей т туризму (WTTC) рекомендують територі льним гром д м розвив ти с ме нішевий туризм.

н лізуючи н ведені в літер турі визн чення нішевого туризму (див. т бл. 2), можн виділити дві н йв жливіші його озн ки, с ме: н ціленість н чітко окреслений, відносно ст лий спеці лізов ний ринковий сегмент т н явність дресних туристичних продуктів, тісно прив'яз них до потреб спожив чів.

и не усі виділені укр їнськими втор ми спеці лізов ні види туризму у з рубіжній літер турі відносять до “нішевого туризму”. прикл д, . овеллі, вторк книги “ ішевий туризм: суч сні проблеми, тренди й прикл ди” [21], н лізує нішевий туризм як певний континіум ( бо спектр), н одному кінці якого виділяють відносно великі гомогенні ринкові сегменти - м кроніші (н прикл д, культурний, сільський, спортивний чи екологічний туризм), які можуть д лі бути розділені н мікроніші, н другому невеликі вузькоспеці лізов ні сегменти, які не підд ються под льшій сегмент ції [21].

ля виділення ніш вторк пропонує з стосовув ти три основні підходи:

) геогр фічний і демогр фічний підхід - ключову роль відігр є особливість туристичної дестин ції чи її н селення, що є в жливим для здійснення певної специфічної туристичної діяльності (н прикл д, міський, сільський туризм, дж йлоо-туризм бо туризм до племен (tribal tourism);

б) продукт-орієнтов ний підхід - пов'яз ний з особливостями туристичного продукту: специфічними ресурс ми, тр кціями, послуг ми чи туристичними з няттями, підібр ними відповідно до специфічних потреб т поб ж нь туристів (екотуризм, г строномічний туризм, шоп-туризм);

в) клієнт-орієнтов ний підхід, пов'яз ний з особливостями спожив чів, їхніми очікув ннями т вимог ми, спеці льними інтерес ми (н прикл д, туризм для неповноспр вних, дитячий туризм, - -туризм) [21]. 
умунські втори . отік, . лекс ндру, . ерзі (V. Zotic, D. Alexandru, S. Dezsi) вв ж ють нішевий туризм одною з н йх р ктерніших тенденцій туризму епохи постмодернізму [26]. жливою рисою нішевого туризму, н їхню думку, є тісний вз ємозв' язок між туристичною пропозицією і попитом н мікрорівні. ішевий туризм предст влений численними в рі ціями в широкому ді п зоні, не обов'язково чітко визн ченими чи обмеженими певними р мк ми. еред інших б зових особливостей втори н зив ють т кі:

- підтримк регіон льного (місцевого) економічного розвитку, тобто перенесення кцентів з м крорівня н м крорівень;

- дослідження т з лучення нових туристичних ресурсів (зокрем , екологічних, геот біоресурсів);

- відкриття нових ринків спожив чів з чітко визн ченими преференціями;

- ст ле (зрівнов жене) використ ння туристичних ресурсів т зменшення нег тивного впливу н довкілля;

- ктивн уч сть туристів, більш тісні стосунки між турист ми т місцевим н селенням дестин ції;

- ширший ді п зон продуктів, більш комплексн т гнучк пропозиція, д птов н до потреб т можливостей потенційних спожив чів [26].

вдяки цим особливостям нішевий туризм може д лі зрост ти і диверсифікув тися н велику кількість типів і підтипів. думку вторів, цей процес зн ходиться лише н поч тку свого розвитку, тому перелік мікроніш (і відповідних їм видів туризму) в рто з лишити відкритим, дже постійно з'являються “нові (нещод вно виниклі)” види нішевого туризму [26].

онцепція нішевого туризму є яскр вим прикл дом втілення т к зв ної теорії “довгих хвостів" (“long tail”) в економіці, як передб ч є можливість отримув ти прибуток, виробляючи продукцію в меншому об’ємі з р хунок збільшення різном нітності продуктів. погляду туризму це озн ч є створення великої кількості спеці лізов них туристичних продуктів для невеликих ринкових ніш. окрем , у книзі “ овгий хвіст туризму. ідпочинкові ніші т їхній вплив н провідні н прями туризму” з ред кцією п т н сіс про н лізов но 20 видів туризму, що відповід ють спеці лізов ним ринковим ніш м, т розглянуто перспективи розвитку туризму з "long tail”-сцен рiєм [22].

орівнюючи поняття “туризм спеці льного інтересу” т “нішевий туризм”, н підст ві зг д них вище літер турних джерел, можн зробити т кі висновки: обидв підходи виникли як льтерн тив м совому туризму у відповідь н зрост ючі потреби туристів; SIT є вужчим поняттям ніж нішевий туризм, оскільки передб ч є обов'язкову н явність у туристів певного спеці льного інтересу, який виступ є ключовим мотивом до подорожі; SIT є скл довою ч стиною нішевого туризму.

ітчизняний термін “спеці лізов ний туризм”, н н ш погляд, більше відповід є поняттю нішевого туризму в іноземній літер турі. еякі суч сні укр їнські втори, уже пропонують дуже близькі визн чення, стверджуючи, що “спеці лізов ний” - це т кий, що призн чений для окремого сегменту ринку, ін кше к жучи, для певної ринкової ніші.

н лізуючи проблем тику спеці лізов ного т нішевого туризму, потрібно т кож коротко сх р ктеризув ти ще одне поняття - “кв ліфіков ний туризм”. оно з'явилося ще в 50-х рок х ст. у польській туризмозн вчій літер турі, як є доволі популярною в

кр їні. ермін "turystyka kwalifikowana" виник у середовищі ольського туристичнокр єзн вчого тов риств (РТТК). утність поняття “кв ліфіков ний туризм”, т кож 
його місце серед т ких к тегорій, як ктивний, спортивний т пригодницький туризм, висвітлено в публік ціях б г тьох польських вторів (Т. Łobo ewicz, 1983; W. Kurek, M. Mika, E. Pitrus, 2007; M. Durydiwka, 2010; B. Bończak, 2013; J. Mokras-Grabowska, 2015). р ктерними рис ми кв ліфіков ного туризму, н думку більшості вторів, є: обов'язкові фізичні н в нт ження, особист кв ліфік ція турист, необхідність спецільної психофізичної підготовки чи тренув нь; високий рівень обізн ності турист 3 м ршрутом чи територією; у деяких вип дк х - користув ння спеці льним спорядженням, кв ліфік ція досягнень турист у вигляді певних рівнів чи відзн к. г лом вв ж ють, що він $є$ н йбільш спеці лізов ною формою ктивного туризму, н йвищою формою туристичної спеці ліз ції.

польській туризмозн вчній літер турі є т кож поняття “turystyka specjalistyczna". одо його використ ння, як і в кр їні, нем є єдиної думки. еякі втори ототожнюють кв ліфіков ний і спеці лізов ний туризм, інші вв ж ють перше поняття вужчим. ід вплив нгломовної літер тури у ольщі щор зу ч стіше використовують поняття "turystyka specjalnych zainteresowań”, н логічне нгломовному SIT.

тже, поняття “спеці лізов ний туризм” в укр їнській н уковій літер турі т н постр дянському просторі, н н ш погляд, є відповідником нішевого туризму в іноземних джерел $\mathrm{x}$, його використовують для позн чення н логічних явищ т тенденцій у туристичній г лузі, які виникли в ост нні десятиріччя - -н поч тку XXI ст. як льтерн тив м совому туризму.

икорист ння різних термінів зумовлене типологічними відмінностями економік, які функціонув ли в минулому у т. зв. “к піт лістичних" i “соці лістичних” кр їн х. умов х ринкової економіки в з хідній н уковій економічний літер турі ктивно використовув ли м ркетинговий термін “ринков ніш ", який і ст в попередником поняття "нішевий туризм”. томість для колишнього і кр їн “соці лістичного т бору” з дміністр тивно-регульов ною економікою х р ктерніше вжив ння понять “спеці ліз ція”, “г лузь спеці ліз ції”, с ме тому тут тр диційно скл вся термін “спеці лізов ний туризм”.

тже, спеці лізов ний (нішевий) туризм - це сукупність видів туризму, орієнтов них н чітко окреслені й відносно ст лі групи туристів (об'єдн ні з мотив ми подорожі, спеці льними потреб ми туристів, чи особливостями туристичної дестин ціі), що формують певний вузький цільовий сегмент ринку (мікронішу), дост тній з величиною для створення окремих туристичних продуктів.

йв жливішими озн к ми, які д ють змогу віднести певний вид туризму до спеці лізов ного, є:

- н явність чітко окресленої і відносно ст лої цільової групи туристів;

- виділення ринкової ніші н основі сегмент ції ринку спожив чів;

- орієнт ція н вузький цільовий сегмент, бо н мікроринок;

- дост тність ніші для створення окремих туристичних продуктів;

- дресний, чітко визн чений туристичний продукт, тісно підігн ний до специфічних вимог спожив чів.

евідповідність виду туризму одній бо декільком з перелічених вище озн к може свідчити про те, що:

- він відноситься до м сового туризму (якщо не виконується умов орієнт ції н вузький цільовий сегмент);

- він є “неринковим продуктом” (якщо неможливо виділити ринкову нішу); 
- це ситу тивне явище в туризмі (якщо не м ємо ст лої у ч сі чітко окресленої групи туристів);

- це новий вид туризму, для якого ще нем є сформов ної ніші, бо обсяги якої ще не дост тні для того, щоб фірм створюв л і успішно просув л н ринку туристичний продукт.

ля кл сифік ції спеці лізов них видів туризму, н н шу думку, доцільно використовув ти критерії, н підст ві яких здійснюють сегмент цію ринку т виділення окремих ринкових ніш. першу чергу це мет подорожі, т кож особливості туристичної дестин ції т спеці льні потреби туристів. дн к в рто з зн чити, що спеці лізов ний (нішевий) туризм включ є широкий ді п зон видів т підвидів туризму, які не 3 вжди підд ються чіткому визн ченню т кл сифік ції, особливо з огляду н постійне розширення їхнього переліку.

пеці лізов ний (нішевий) туризм - це дин мічне поняття, яке постійно еволюціонує з розвитком туристичної г лузі. ін з лежить від історичного періоду, т кож від рівня розвитку туризму в певній кр їні (регіоні). овий іннов ційний вид туризму, н був ючи популярності, може споч тку ст ти нішевим, потім - м совим. цьому контексті з ув жимо, що туризм н $\mathrm{p}$ нніх ет п х свого розвитку т кож був усього-н -всього одним із нішевих видів діяльності в сфері послуг.

ьогодні у розвитку спеці лізов ного туризму можн відзн чити дві протилежні тенденції: 1) под льш диверсифік ція ринку, появ нових мікроніш (i, відповідно, нових вузькоспеці лізов них видів туризму); 2) розширення ринкових сегментів 3 вдяки зрост нню попиту н певні спеці лізов ні види туризму, що веде до їх поступової еволюції в н прямі м сового туризму.

1. ндрєєв . ., ов ль . . еоретичні з с ди спеці лізов ного туризму // лоб льні т н ціон льні проблеми економіки. 2015. ип. 7. . 90-94.

2. брицьк . ., линовськ . . енеджмент туризму. уроперейтинг. онятійно-термінологічні основи, сервісне з безпечення турпродукту : н вч. посібник. . : льтерпрес, 2004. 288 с.

3. бкин . . пеци льные виды туризм : учеб. пособие. . : - ., 2003.316 с.

4. иржкков . . пеци льные виды туризм : конспект лекций. б.: б, , $2011.70 \mathrm{c}$.

5. оголюбов . . рг низ ция специ льных видов туризм . б. : , 2010.116 с.

6. утчк. ., утчк . . еякі спекти виділення сегментів спеці лізов ного туризму т їх ст н н території ернівецької обл сті // уристсько-кр єзн вчі дослідження. . : рм літ , 1999. ип. 2. . 123-136.

7. нциклопедичний словник-довідник з туризму / упоряд. . . . молій, . едорченко, . . ибух [з з г. ред. . . едорченк ]. . : лово, 2006. 372 с.

8. іптенко . . енеджмент туризму : підручник. . . н ння, 2010. 502 с.

9. $р$ чило . . еогр фия туризм . . : ищ школ , 1987. 205 с.

10. вин . ., рядов . . пеци льные виды туризм : учеб. пособие. росл вль : p им. . . емидов , 2013.128 с.

11. стименко . . сторико-суспільні спекти розвитку спеці лізов ного туризму // ит ння культурології. 2013. N 29. С. 138-145. 
12. Bończak B. Turystyka aktywna, kwalifikowana czy sportowa? Wzajemne relacje między zjawiskami w świetle literatury polskiej i zagranicznej // Współczesne uwarunkowania i problemy rozwoju turystyki / R. Pawlusiński (red.). Kraków: Wyd. Uniwersytetu Jagiellońskiego, 2013. S. 121-134.

13. Derrett $R$. Special interest tourism: starting with the individual // Special interest tourism / N. Douglas, R. Derrett (Eds.). Brisbane : Wiley, 2001. P. 1-28.

14. Developing a Niche. Tourism Market. Database for the Caribbean / 20 Niche Market Profiles. Caribbean Tourism Organisation. Acorn Consulting Partnership Ltd. 2008.

15. Durydiwka M. Definicja i zakres pojęcia "turystyka kwalifikowana (turystyka aktywna)" // Turystyka zrównowa ona / A. Kowalczyk (red.). PWN. Warszawa, 2010. S. 249-289.

16. Hall M., Weiler B. (Eds.). Introduction. What's special about special interest tourism? // Special interest tourism. Bellhaven Press, 1992. P. 1-14.

17. Kurek W., Mika M., Pitrus E. Formy turystyki kwalifikowanej // Turystyka / W. Kurek (red.). Wyd. Naukowe PWN, 2007. S. 256-279.

18. Łobo ewicz T. Turystyka kwalifikowana. Warszawa : Wyd. PTTK "Kraj”, 1983.

19. Mokras-Grabowska J. (2015) Ró norodność metod teoretycznych i form podejść w turystyce aktywnej // Badania nad turystyką. Jeden cel, ró nepodejścia. Warsztaty z Geografii Turyzmu / B. Włodarczyk (red.). Łódź : Wyd. Uniwersytetu Łódzkiego, 2015. T. 6. S. 117-129.

20. Mokras-Grabowska J. Turystyka aktywna - zagadnienia terminologiczne i klasyfikacje // Wczoraj, dziś i jutro turystyki aktywnej i specjalistycznej / Pod red. nauk. A. Stasiaka, J. Śledzińskiej i B. Włodarczyka. Warszawa : Wydawnictwo PTTK “Kraj”, 2015. S. 11-25.

21. Novelli M. Niche Tourism: Contemporary issues, trends and cases / Marina Novelli (Ed.). Oxford and Burlington : Elsevier Butterworth Heinemann, 2005.

22. Papathanassis A. (Ed.). The Long Tail of Tourism. Holiday Niches and their Impact on Mainstream Tourism. Wiesbaden, Gabler, 2011. 220 p.

23. Read S. E. A prime force in the expansion of tourism in the next decade: special interest travel// Tourism Marketing and Management Issues / E. L. Hawkins, E. L. Shafer, J. M. Rovelstad (Eds.). Washington: The George Washington University Press, 1980. P. 193-202.

24. Smith M., Macleod N., Robertson M. H. Key Concepts in Tourist Studies. London: SAGE, 2010.

25. Swarbrook J., Horner S. Consumer behaviour in tourism. Oxford: Butterworth and Heinemann, 1999.

26. Zotic V., Alexandru D. E., Dezsi S. Debate on Tourism in Postmodernism and Beyond // Proceedings of the 2nd Belgrade International Tourism Conference. Serbia, 2014. P. 79-98.

\section{REFERENCES}

1. Andrieieva, H., \& Koval, P. (2015). Theoretical foundations of specialized tourism. Global and national problems of the economy, 7, 90-94 (in Ukrainian).

2. Babarytska, V., \& Malynovska, O. (2004). Tourism Management. Tour operating. Conceptual and terminological foundations, service support for tourist products. Kyiv: Alterpres (in Ukrainian).

3. Babkin, A. (2003). Special types of tourism. Moscow: INFRA-M (in Russian). 
4. Birzhakov, M. (2011). Special types of tourism: abstract lectures. St. Petersburg: St. Petersburg University Pub. (in Russian).

5. Bogolyubov, V. (2010). Organization of special types of tourism. St. Petersburg: St. Petersburg Engineering and Economic University Pub. (in Russian).

6. Dutchak, S. V., \& Dutchak, M. V. (1993). Several aspects of the allocation of segments of specialized tourism and their condition on the territory of Chernivtsi region. Tourist-lore studies, 2, 123-136 (in Ukrainian).

7. Fedorchenko, V. K. (Ed.) (2006). Encyclopedic Vocabulary-Dictionary of tourism. Kyiv: Word (in Ukrainian).

8. Kiptenko, V. K. (2010). Tourism Management. Kyiv: Knowledge (in Ukrainian).

9. Krachylo, N. P. (1987). Geography of tourism. Kyiv: High school (in Ukrainian).

10. Savyn, D. A., \& Uriadova, A. V. (2013). Special types of tourism. Yaroslavl: Yaroslavl University Pub. (in Russian).

11. Ustymenko, L. M. (2013). Historical and social aspects of the development of specialized tourism. Questions of cultural science, 29, 138-145 (in Ukrainian).

12. Bończak, B. (2013). Turystyka aktywna, kwalifikowana czy sportowa? Wzajemne relacje między zjawiskami w świetle literatury polskiej i zagranicznej. In R. Pawlusiński (Ed.), Wspótczesne uwarunkowania i problemy rozwoju turystyki (pp. 121-134). Kraków: Wyd. Uniwersytetu Jagiellońskiego (in Polish).

13. Derrett, R. (2001). Special interest tourism: starting with the individual. In N. Douglas \& R. Derrett (Eds.), Special interest tourism (pp. 1-28). Brisbane: Wiley.

14. Developing a Niche (2008). Tourism Market. Database for the Caribbean. 20 Niche Market Profiles. For: Caribbean Tourism Organisation. From: Acorn Consulting Partnership Ltd.

15. Durydiwka, M. (2010). Definicja i zakres pojęcia "turystyka kwalifikowana (turystyka aktywna)". In A. Kowalczyk (Ed.), Turystyka zrównowa ona (pp. 249-289). Warszawa: PWN (in Polish).

16. Hall, M., \& Weiler, B. (Eds.). (1992). Introduction. What's special about special interest tourism? Special interest tourism (pp. 1-14). Bellhaven Press.

17. Kurek, W., Mika, M., \& Pitrus, E., (2007). Formy turystyki kwalifikowanej. In W. Kurek (Ed.), Turystyka (pp. 256-279). Warszawa: Wyd. Naukowe PWN (in Polish).

18. Łobo ewicz, T. (1983). Turystyka kwalifikowana. Warszawa: Wyd. PTTK "Kraj" (in Polish).

19. Mokras-Grabowska, J. (2015). Ró norodność metod teoretycznych i form podejść w turystyce aktywnej. In B. Włodarczyk (Ed.), Badania nad turystykq. Jeden cel, ró nepodejścia, Warsztaty z Geografii Turyzmu (pp.117-129), 6. Łódź: Wyd. Uniwersytetu Łódzkiego (in Polish).

20. Mokras-Grabowska, J. (2015). Turystyka aktywna - zagadnienia terminologiczne i klasyfikacje. In A. Stasiak, J. Śledzińska \& B. Włodarczyk (Eds.), Wczoraj, dziś i jutro turystyki aktywnej i specjalistycznej (pp. 11-25). Warszawa: Wydawnictwo PTTK "Kraj” (in Polish).

21. Novelli, M. (Ed.). (2005). Niche Tourism: Contemporary issues, trends and cases. Oxford and Burlington: Elsevier Butterworth Heinemann.

22. Papathanassis, A. (Ed.). (2011). The Long Tail of Tourism. Holiday Niches and their Impact on Mainstream Tourism. Wiesbaden, Gabler. 220 p. 
23. Read, S. E. (1980). A prime force in the expansion of tourism in the next decade: special interest travel. In E. L. Hawkins, E. L. Shafer \& J. M. Rovelstad (Eds.). Tourism Marketing and Management Issues (pp. 193-202). Washington: The George Washington University Press.

24. Smith, M., Macleod, N., \& Robertson, M. H. (2010). Key Concepts in Tourist Studies. London, SAGE.

25. Swarbrook, J., \& Horner, S. (1999). Consumer behaviour in tourism. Oxford: Butterworth and Heinemann.

26. Zotic, V., Alexandru, D. E., \& Dezsi, S. (2014). Debate on Tourism in Postmodernism and Beyond, The Business of Tourism, 13, June 2014, 79-93.

m ття: н дійшл до ред киї̈ 01.04.2018

доопр иьов н 25.04.2018

прийнят до друку 12.06.2018

\title{
SPECIALIZED (NICHE) TOURISM: DEVELOPMENT OF THE CONCEPT IN UKRAINIAN AND FOREIGN ACADEMIC LITERATURE
}

\author{
Roman Lozynskyy ${ }^{1}$, Iryna Kuchynska² \\ ${ }^{1}$ Ivan Franko National University of Lviv, \\ P. Doroshenko St., 41, UA - 79007 Lviv, Ukraine, \\ e-mail:lrm@ukr.net \\ ${ }^{2}$ West Ukrainian Ornithological Society, \\ Kleparivska St., 25a, UA - 79007 Lviv, Ukraine, \\ e-mail: ikuchynska@gmail.com
}

The term "specialized tourism" has been widely used in Ukrainian academic literature for the last few decades. The analysis of main publications reveals that this term refers to different types of tourism, which are usually known as "niche tourism" in the foreign literature. Another term "special interest tourism" or SIT sounds very similar, but in fact, it has a bit different and narrower meaning.

Such a difference in terms between Ukrainian and English-language publications is caused by differences in economic systems of so-called "capitalist" and "socialist" countries in the past. The term "niche tourism" comes from the concept of "niche market", which appeared in the western economic literature under conditions of market economy. Instead, in the former USSR, in terms of a command economy, the concept of "specialization" was more popular, so the term "specialized tourism" appeared.

Due to the analysis of the development of the concept of specialized (niche) tourism in domestic and foreign academic literature we got the possibility to clarify its contemporary content.

Specialized (niche) tourism is a set of different types of tourism, targeted at clearly defined and relatively stable groups of tourists forming market segments (microniches), quite narrow but sufficient for the creation of individual tourist products. Niches can be separated based on different criteria such as the purpose of travelling, special needs of tourists or special features of tourism destinations.

The most important features of specialized (niche) tourism are as follows: well-defined and relatively stable target group of tourists; market segmentation based on aforementioned criteria; products targeted at narrow market segments (micronishes) and tailored to the specific requirements of tourists; niche size sufficient for the creation of individual tourist products.

Key words: tourism, types of tourism, specialized tourism, niche tourism, special interest tourism, tourist product. 